\title{
EFFECT OF PHYSICAL EXERCISE ON MEDICAL REHABILITATION TREATMENT OF DEPRESSION
}

EFEITO DE EXERCÍCIOS FÍSICOS NO TRATAMENTO MÉDICO PARA REABILITAÇÃO DA DEPRESSÃO

EFECTOS DE EJERCICIOS FÍSICOS EN EL TRATAMIENTO MÉDICO PARA REHABILITACIÓN DE LA DEPRESIÓN

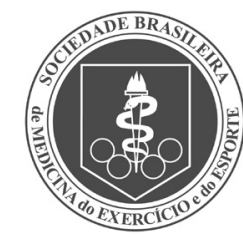

Original Article ARTIGO ORIGINAL Artículo Original

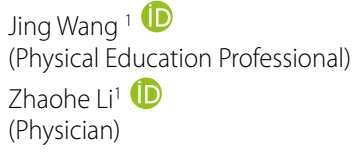

1. Ministry of Physical Education, Education and Research, Northeast Agricultural University, Harbin, China.

\section{Correspondence:}

Zhaohe Li

Harbin, China. 150001.

lizhaohe20212021@163.com

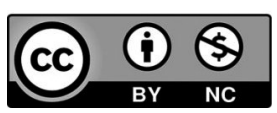

\begin{abstract}
Introduction: Depression is a common disease worldwide. The main treatment methods currently include medication, psychotherapy, and physical therapy. However, due to limitations in treatment methods, treatment compliance is poor. Participating in various sports is very effective in treating depression. Objective: To verify the influence of sports on the condition of depression and on the effect of its clinical treatment. Methods: The article selected a total of 60 hospitalized patients with depression who were randomly divided into two groups: an experimental group and a control group. The control group took antidepressant drugs for eight weeks, and the experimental group took the drugs with the supplementary practice of sports. The two groups of patients were tested for serum $\beta$-endorphin ( $\beta$-EP) levels before and after treatment, and HAMD scores were performed. Results: The scores and serum $\beta$-endorphin ( $\beta$-EP) levels of the two groups of patients were different, showing that effect of the treatment was better in the experimental group. Conclusion: Physical exercise therapy can mobilize the enthusiasm of patients with depression. This treatment plan increases treatment efficiency and is suitable for long-term clinical promotion and application. Level of evidence Il; Therapeutic studies - investigation of treatment results.
\end{abstract}

Keywords: Sports; Depression; Endorphins; Exercise Therapy.

\section{RESUMO}

Introdução: A depressão éuma doença comum em todo o mundo. Os principais métodos de tratamento atuais incluem medicação, psicoterapia e fisioterapia. Contudo, graças às limitações dos métodos de tratamento, a aderência a eles é pequena. Participar de vários esportes é uma maneira eficiente de se tratar a depressão. Objetivo: Verificar a influência de esportes na condição depressiva e seu efeito no tratamento clínico da doença. Método: Selecionou-se 60 pacientes hospitalizados, que foram aleatoriamente divididos em dois grupos: um grupo experimental e um grupo controle. O grupo controle tomou antidepressivos por oito semanas, e o grupo experimental usou os medicamentos somados à prática de esportes. Testou-se os níveis de beta-endorfina ( $\beta$-EP) dos dois grupos antes e depois do tratamento, e a pontuação na escala HAMD foi avaliada. Resultados: Houve diferença na pontuação e nos níveis de $\beta$-EP entre os grupos, indicando que o efeito do tratamento foi melhor no grupo experimental. Conclusão: A terapia com exercício físico écapaz de mobilizar o entusiasmo dos pacientes com depressão. Esse plano de tratamento aumenta a eficiência da terapia e é adequado para promoção e aplicação a longo prazo. Nível de evidência Il; Estudos terapêuticos - investigação de resultados de tratamento.

Descritores: Esportes; Depressão; Endorfinas; Terapia por Exercício.

\section{RESUMEN}

Introducción: La depresión es una enfermedad común en todo el mundo. Los principales métodos de tratamiento actuales incluyen medicación, psicoterapia y fisioterapia. Sin embargo, gracias a las limitaciones de los métodos de tratamiento, la adherencia a los mismos es baja. Practicar varios deportes es una forma eficaz de tratar la depresión. Objetivo: Verificar la influencia de los deportes en la condición depresiva y su efecto en el tratamiento clínico de la enfermedad. Método: Se seleccionaron 60 pacientes hospitalizados, que fueron aleatoriamente divididos en dos grupos: un grupo experimental y un grupo control. El grupo control tomó antidepresivos por ocho semanas, y el grupo experimental usó los medicamentos sumados a la práctica de deportes. Se analizaron los niveles de betaendorfina ( $\beta$-EP) de ambos grupos antes y después del tratamiento, y se evaluó la puntuación de la escala HAMD. Resultados: Hubo diferencia en la puntuación y en los niveles de $\beta$-EP entre los grupos, indicando que el efecto del tratamiento fue mejor en el grupo experimental. Conclusión: La terapia con ejercicio físico es capaz de movilizar el entusiasmo de los pacientes con depresión. Este plan de tratamiento aumenta la eficacia de la terapia y es adecuado para la promoción y aplicación a largo plazo. Nivel de evidencia ll; Estudios terapéuticos - investigación de resultados de tratamiento.

Descriptores: Deportes; Depresión; Endorfinas; Terapia por Ejercicio. 


\section{INTRODUCTION}

The continuous increase of social development work and social employment pressure has led to an increasing number of people suffering from depression, which has caused great economic losses to society and families. Many studies have proved that depression is a mental illness with a high prevalence, recurrence rate, disease burden, and suicide mortality rate. Depression is the most common of all mental illnesses. It is a syndrome characterized by low mood, slow thinking, and decreased activity, and sluggishness. Some experts speculate that the 21st century is the peak of the onset of psychosomatic diseases. ${ }^{1}$ Psychological problems, especially depression, are constantly threatening people's physical and mental health. Promoting the recovery of depressed patients is of great significance to society as a whole. At present, depression is mainly treated with drugs, psychology, and electric shock. There are reports in the literature that exercise can promote mental health, so few reports and studies on whether exercise promotes the recovery of patients with depression. Therefore, this experiment mainly studies whether exercise can promote the recovery of depression.

\section{METHOD}

\section{Research object}

We selected 68 inpatients in the hospital from June 2019 to June 30, 2021. The patient met the "Chinese Classification and Diagnostic Criteria for Mental Disorders (3rd Edition)"for the diagnosis of depression. ${ }^{2}$ The total score of the Hamilton Depression Scale (HAMD, 17 items) $\geq 17$ points. Exclude other mental illnesses, alcohol and drug dependence, severe central nervous system diseases, hematopoietic diseases, angle-closure glaucoma, epilepsy, physical allergies, pregnant and lactating women. There was no significant difference between the two groups in gender, age, education level, and disease course ( $p>0.05)$.

\section{Research methods}

Randomized patients will be divided into two groups: a control group and the experimental group. Among them, the control group only took the depression drug Biyoujie 20mg/day and took it at breakfast. ${ }^{3}$ In addition to taking the same drugs as the control group, the experimental group jogged 3-5 times a week for 30-60 minutes each time. According to the adult healthy running 170 minus the age of the heart rate to control the exercise intensity, the heart rate is controlled at 120-150 beats/min. We use the American ACUMEN heart rate measuring instrument by nurses to measure the patient's heart rate. Blood was drawn 30 minutes after the last exercise every week in the experimental group and sent to determine the serum $\beta$-endorphin content. The control group and the experimental group also had blood drawn and submitted for testing. Each person draws $5 \mathrm{ml}$ of blood without anticoagulation. Radioimmunoassay (RIA) was used to detect patients' serum $\beta$-endorphin ( $\beta$-EP) content after exercise. The Beijing Northern Institute of Biotechnology provided the radioimmunoassay kit. Four patients in the experimental group actively asked to withdraw from the trial but did not affect the experiment results. The treatment time is eight weeks. Before treatment and at 2, 4, 6, and 8 weeks of treatment, the reduction rate of the HAMD scale was used to evaluate the curative effect. Evaluate the curative effect: if the score reduction rate is greater than $75 \%$, it is cured, greater than $50 \%$ is marked improvement, greater than $30 \%$ is improved, and less than 30\% is invalid. ${ }^{4}$ There was no significant difference in AMD scores between the two groups before treatment and at the time of enrollment $(P>0.05)$.

\section{Sports muscle biomechanics}

$f_{2}$ represents the frequency of muscle contraction in different training phases. $e_{(f)}$ represents the dynamic characteristics of a single action potential at a certain point on the muscle membrane. Changes in $\mathrm{Ca}^{2+}$ in muscle segments caused by training load. $\chi^{(t)}, g^{(t)}$ represents the change state of muscle yield load and maximum load under different training conditions. ${ }^{5}$ Then use formula (1) to get the muscle movement state of different training stages

$$
M_{(W)}^{*}=\frac{f_{2} \otimes e_{(f)}}{\left[\chi^{(t)} \llbracket g^{(t)}\right]} \vartheta(\omega) \times Q(k)
$$

$\vartheta(\omega)$ represents the spatial relationship between muscle fibers and bones. $Q(k)$ represents the total length of the tendon. $\partial(j, p)$ represents the muscle influence sample under historical sports training. $k(p, o)$ represents the influence of the training load on the muscles at different moments. Use $\partial(j, p)$ and $k(p, o)$ as the input and output values of the neural network. $E(j)$ represents the physiological structure of muscles. ${ }^{6}$ Using the formula (1) fused with neural network theory, we build a muscle influence model under sports training

$$
\psi(o, j)=\frac{[\partial(j, p) * k(p, o)]}{\varphi(\mathfrak{I}) * \gamma(j, p)} \otimes \xi
$$

$\varphi(\mathfrak{I})$ represents the predicted value of muscle strength of the lateral head of the lower limbs lateral femoris and geniculate muscle. $\gamma(j, p)$ represents the actual sampling value that affects the muscles under sports training. $\xi$ represents the error between the actual sampled value and the output.

\section{Statistical analysis}

The curative effect of the two groups of patients was evaluated by HAMD reduction rate and t-test. ${ }^{7}$ The degree of depression was evaluated and tested by the HAMD reduction rate. We use SPSS13.0 for data analysis.

\section{RESULTS}

\section{Comparison of curative effect between the control group and experimental group}

After eight weeks of treatment, the indicators in the two groups had improved to a certain extent, but the improvement in the experimental group was more significant. ${ }^{8}$ The degree of improvement is much greater than that of the control group ( $X 2=0.012, P<0.05$, Table 1).

\section{Comparison of symptom evaluation of depression in diffe- rent stages of treatment between the two groups}

The comparison of the depression evaluation scores of the two groups of patients at different stages of treatment is shown in Table 2. It can be seen from Table 2 that the effects of the control group and the experimental group are more obvious in the first few weeks. ${ }^{9}$ In the

Table 1. Observation of the curative effect of the control group and the experimental group.

\begin{tabular}{c|c|c|c|c|c|c}
\hline Group & $\begin{array}{c}\text { Number } \\
\text { of cases }\end{array}$ & Get well & $\begin{array}{c}\text { Markedly } \\
\text { effective }\end{array}$ & $\begin{array}{c}\text { Get } \\
\text { better }\end{array}$ & Invalid & Efficient\% \\
\hline Control group & 30 & 7 & 6 & 5 & 13 & 56 \\
\hline Test group & 30 & 12 & 8 & 6 & 4 & 87 \\
\hline
\end{tabular}

Table 2. Comparison of symptom evaluation of depression in different stages of treatment between the two groups.

\begin{tabular}{c|c|c|c|c|c}
\hline Group & On admission & Two weeks & Four weeks & Six weeks & Eight weeks \\
\hline Control group & $35 \pm 3.21$ & $32 \pm 3.10$ & $28 \pm 3.16$ & $24 \pm 3.62$ & $20 \pm 4.01$ \\
\hline Test group & $34 \pm 3.16$ & $31 \pm 2.45$ & $26 \pm 2.87$ & $12 \pm 3.45$ & $8 \pm 4.15$ \\
\hline
\end{tabular}


sixth week, the effect was significantly different from the experimental group than the drug group. Test results for two related samples: $t$ value is -2.670 , the $p$-value is 0.008 . We can think that the treatment effect of the experimental group is significant.

\section{Comparison of serum $\beta$-EP content between the two groups of patients at different stages of treatment}

There was no difference in serum $\beta$-EP between the two groups of patients on admission. ${ }^{10}$ From the second week, the serum $\beta$-EP content of the experimental group was significantly higher than that of the control group (Table 3).

Table 3. Comparison of serum $\beta$-EP content (pg/uL) between the two groups of patients at different stages of treatment.

\begin{tabular}{c|c|c|c|c|c}
\hline Group & On admission & Two weeks & Four weeks & Six weeks & Eight weeks \\
\hline Control group & $25.23 \pm 4.06$ & $25.47 \pm 3.23$ & $24.72 \pm 5.12$ & $24.91 \pm 6.03$ & $26.43 \pm 2.45$ \\
\hline Test group & $24.47 \pm 5.33$ & $35.16 \pm 7.84$ & $36.73 \pm 8.51$ & $36.31 \pm 6.80$ & $38.41 \pm 9.17$ \\
\hline
\end{tabular}

\section{DISCUSSION}

Depression is a mental disorder. Mainly manifested as depression, indifference to external things and accompanied by some physical symptoms, such as loss of appetite, insomnia, weight loss, etc. According to the WHO global burden of disease data, the loss of disability-adjusted life years (DALYS) caused by depression in China is 6.9\%. It ranks No. 2 among all diseases and is close to Western developed countries. Although domestic epidemiological data shows that the prevalence of depression in community population is significantly lower than that in Western countries (20-100 times), the questionnaire survey of outpatients in general hospitals and inpatients in internal and external departments found that about 10-30\% Of patients are accompanied by depressive symptoms. This ratio is similar to foreign data. Due to mental factors, patients with depression rarely take medication and other treatments consciously. Persuade the patient to be able to do some sports. Exercise means removing bad factors from the mental aspect, exercising people's will, strengthening perseverance, and improving the body's resistance. The body's increased metabolic activity during exercise helps eliminate the accumulated adrenaline and other metabolic waste products. It allows the blood stored in the liver, spleen, and other organs to enter circulation in large quantities. Exercise can make the blood perfusion of important organs such as brain tissue and myocardium tissue good and contribute to their nutrient supply. It is helpful for patients to go to sleep to relieve anxiety and help the recovery of depression. $\beta$-EP synthesis sites are mainly the basal part of the hypothalamus. It participates in emotion regulation together. Exercise can cause a significant increase in the concentration of endogenous opioid peptides, especially $\beta$-EP and $\beta$-lipotropin. $\beta$-EP can make people feel euphoria and increase pain tolerance. The release of this hormone can change appetite, reduce anxiety and tension. It can relieve the symptoms of depression very well. Endorphins are a powerful morphine hormone secreted and released by the pituitary gland during aerobic exercise. American medical scientists have proved that $\beta$-EP has a strong analgesic effect similar to morphine, and the effect of equivalent $\beta$-EP is 200 times stronger than that of morphine in dose analogy. The human body can maintain a high level of $\beta$-EP during long-term exercise (above 60 minutes). Some psychiatric experts recommend aerobic metabolic exercise as one of the methods to treat mental illness. The reason is that $\beta$-endorphin can alleviate the emotional symptoms of mental illness and is a good mood stabilizer. It can be seen from the clinical test that the serum $\beta$-EP content of the patients in the experimental group after participating in exercise is higher than that of the patients in the control group. According to this, the symptoms of depression patients who insist on a certain intensity of physical exercise will alleviate, related to endorphins. At present, depression and mental stress are more common among many patients. And cause this kind of emotion to be suppressed in the heart not to be vented. If this mental state is not actively guided, it may aggravate its existing state. And exercise can release this tension and increase the patient's self-confidence, thereby reducing this depressed psychological state. Drug-based patients often receive treatment passively, and their depression cannot be released without contact with the outside world, so the remission of their illness is slower.

\section{CONCLUSION}

From the comparison between the control and experimental groups, the recovery of patients in the experimental group is obvious. This experimental study provides a feasible method for the clinical treatment of depression patients. This is worth promoting.

All authors declare no potential conflict of interest related to this article

AUTHORS' CONTRIBUTIONS: Each author made significant individual contributions to this manuscript. Jing Wang: writing and performing surgeries; Zhaohe Li: data analysis and performing surgeries, article review, and intellectual concept of the article.

\section{REFERENCES}

1. Ghasemi Pirbalouti M, Shariat A, Ghazanfari A. A meta-analysis of exercise Therapy on reducing depression among older adults in Iran. Quarterly Journal of Health Psychology. 2019;8(30):69-80.

2. Hajihasani A, Rouhani M, Salavati M, Hedayati R, Kahlaee A. The influence of cognitive behavioral therapy on pain, quality of life, and depression in patients receiving physical therapy for chronic low back pain: a systematic review. Pm\&r. 2019;11(2):167-76.

3. Van Laake-Geelen CC, Smeets RJ, Quadflieg SP, Kleijnen J, Verbunt JA. The effect of exercise therapy combined with psychological therapy on physical activity and quality of life in patients with painfu diabetic neuropathy: a systematic review. Scandinavian journal of pain: 2019;19(3):433-9.

4. Saeed SA, Cunningham K, Bloch RM. Depression and anxiety disorders: benefits of exercise, yoga, and meditation. American family physician. 2019;99(10):620-7.

5. Sbolli M, Fiuzat M, Cani D, O'Connor CM. Depression and heart failure: the lonely comorbidity. European journal of heart failure. 2020;22(11):2007-17.
6. Schuch FB, Stubbs B. The role of exercise in preventing and treating depression. Current sports medicine reports. 2019;18(8):299-304.

7. Hidalgo JLT, Sotos JR. Effectiveness of Physical Exercise in Older Adults With Mild to Moderate Depression. The Annals of Family Medicine. 2021;19(4):302-9.

8. Gordon CS, Waller JW, Cook RM, Cavalera SL, Lim WT, Osadnik CR. Effect of pulmonary rehabilitation on symptoms of anxiety and depression in COPD: a systematic review and meta-analysis. Chest. 2019;156(1):80-91.

9. Pascoe MC, Parker AG. Physical activity and exercise as a universal depression prevention in young people: A narrative review. Early intervention in psychiatry. 2019;13(4):733-9.

10. Hidalgo JLT. Effectiveness of physical exercise in the treatment of depression in older adults as an alternative to antidepressant drugs in primary care. BMC psychiatry. 2019;19(1):1-7. 